\title{
The Anti-enlightenment Tradition as a Source of Cynicism in the European Union
}

\author{
Tamas Dezso Ziegler ${ }^{1}$ (I)
}

Received: 3 February 2020 / Accepted: 5 November 2020 / Published online: 24 November 2020

(c) The Author(s) 2020

\begin{abstract}
This article analyses the effect of the anti-Enlightenment tradition on the functioning of the European Union. This tradition covers a lack of belief in liberal values, human rights, egalitarianism, the rule of law, individualism, tolerance, and the respectful cooperation among people. Its ideological background is not new: its existence is also the reason why scholars started to talk about post-fascism in the twenty-first century. In a number of European Union member states, where autocratic tendencies have recently been witnessed (like in Hungary or Poland), it started to dominate decision-making, while its presence is also visible elsewhere, like in the UK, Germany, and Italy. This article selects four prime examples (the rule of law backlash, refugee law, Brexit, and changes to the single market) to show how arguments containing elements of the anti-Enlightenment tradition are used in a cynical way to support partisan and oppressive politics while maintaining a seemingly inclusive façade of democratic decision-making. In the European Union, this can result in dubious, un-explained measures and great policy changes both at EU and member state level.
\end{abstract}

Keywords European Union $\cdot$ Human rights $\cdot$ Single market $\cdot$ Refugee crisis $\cdot$ AntiEnlightenment

National Socialism was not an aberration; it was, rather, the product of a dialectical historic process of economic, social, and political forces on one hand, and human hopes and longing for the good life on the other. National Socialism was successful as a mass movement precisely, because it was able to turn long-cherished myths and symbols to its own purposes.

George Mosse (Mosse 1981 p. 1)

Tamas Dezso Ziegler

zieglertamas@tatk.elte.hu

1 Faculty of Social Sciences, Institute for International and Political Studies, Eötvös Loránd University, Pázmány Péter Sétány 1/A, 1114 Budapest, Hungary 


\section{Background}

European integration has gone through numerous crises in recent years, exerting a strong effect on legislation as well as its application and enforcement at the national level. In certain fields, this change-and the divergence it has produced across EU Member States-is so visible that a debate has emerged in European studies about whether the EU is disintegrating altogether (Börzel and Risse 2018; Eppler et al. 2016; Jones 2018; Kelemen 2007; Krastev 2012; Kreuder-Sonnen 2018; Kunz 2013; Scheller and Eppler 2014; Schmitter 2012; Schmitter and Lefkofridi 2016; Taylor 2008; Webber 2014; Vollaard 2018). In that discussion, authors from various ideological and theoretical perspectives have been endeavouring to frame the driving issues.

The current article claims that one reason for this tumult can be found in the political traditions of the Member States and the EU. Recently, a growing number of scholars (Copsey 2013; Finchelstein 2014, 2017; Mammone 2009; Mazower 2016; McGaughey 2018; Stanley 2018; Sternhell 2014; Wodak and Richardson 2013) claim that Western political history contains centuries-old, deeply ingrained political conventions. These patterns have had a vast effect on EU Member States and their cooperation. This also means that, even if the present far-right forces are slightly different from their historical predecessors, many of their rhetorical structures and intellectual elements can be connected to those earlier political streams.

Zeev Sternhell (2009), as does Steven Pinker in a recent bestseller (2018), both claim that two different political-cultural frameworks exist in the Western worldtraditions that have been in competition for hundreds of years. The first tradition (that of the Enlightenment) contains ideas such as humanism and universalism (and, as a result, the respect of human rights), rational decision-making, human dignity, respect for the individual, tolerance, mutual trust, and cooperation among all humans and peoples. This view also supports a practical, more cooperative nationalism. We must highlight that, even though these principles vary in their manifestations across countries (i.e., the Scottish, French, and German Enlightenment were not at all the same), certain common values and rights became established in all of these countries. In referring to the Enlightenment tradition, we mean not only the Anglo-Saxon liberal tradition (based on common law and its achievements, i.e., the human rights and constitutional system we have in the Western world), but also a moderate rationalism conforming with universalism and tolerance (as was present within the French and German Enlightenment (see Hayek 1978). Moreover, one could also add pluralism to these values: if human beings possess certain basic rights, the groups they form (e.g., associations and parties) should have them as well. Please note that this idea is not uncontested: Isaiah Berlin, for example, would stress that the Enlightenment was not pluralist, but was rather monolithic, and had an over-rationalistic interpretation about truth (Berlin 1979, 2002). However, my article follows a different interpretation: that of Zeev Sternhell who, as an ardent critic of Berlin, claims we can track both the notion of pluralism and that of a rational choice in the Enlightenment tradition-without falling into the trap of either relativisation or authoritarianism (Sternhell 2009). This is also the reason why Jeremy Waldron (2014) analyses 
the legal heritage of the Enlightenment, also focusing on legal measures in constitutional settings which strengthen pluralism in the society (Waldron 2014). Consequently, based on the works of Waldron and Sternhell, I regard the Enlightenment as not just an intellectual tradition but also a practical framework of social policy-making. Along these lines, Robert Wokler (2012) calls this 'the Enlightenment Project', i.e., an ongoing project based on the values that drove it. This project is continuously developing (and, sometimes regressing), even today. In summary, the current article uses the term Enlightenment in the same sense as Pinker (2019), that is, in a re-interpreted, evolved form-that has less to do with the original concept and more with how we live today (and express it in common language).

Going further, Sternhell also claims that, concurrent with the Enlightenment, another tradition was born-one comprised of a diverse collection of ideas that, in aggregate, served as a counterpoint to the Enlightenment. This tradition, still extant, wallows and relishes in tribalism (Antonio 2000), identity politics (Fukuyama 2018a), the supremacy and excellence of a single 'chosen' nation, intolerance towards and disdain for other nations, racism, and xenophobia. As it is unable to value the individual in a universal way, it is also unable to understand the relevance of universal human rights. In this way, it bases itself on different forms of social Darwinism, claiming that nations and religions are in a constant struggle with each other. This tradition uses emotional manipulation to attack and effectively abolish pluralism, even at the institutional level. Moreover, as it underrates individualism and universalism, it tries to create hierarchical social structures and authoritarian order as superior to democracy and pluralism. There are some differences in the actual appearance of the tradition from country to country, depending on the domestic culture (e.g., it is almost a given that its Central European version will differ from its English appearance). However, its effects are very similar: the change of values in Western societies is so fundamental that Inglehart and Norris (Norris and Inglehart 2016, 2019) speak of a cultural backlash. Indeed, Inglehart claims that, as a result of this shift, 'the world is experiencing the most severe democratic setback since the rise of fascism in the 1930s' (Inglehart 2018). Most anti-Enlightenment political streams are post-Fascist (it is wrong to call them populist), but democratic political streams can also implement their clichés.

It is a very difficult question to pinpoint when exactly the anti-Enlightenment tradition grows stronger in a society or, in retrospect, when that inflection (or tipping point) may occur: Sternhell only mentions that, at moments of crisis, it gets stronger and that 'during times of general welfare it is not taken seriously' (Salomon 2016). In all likelihood, such a rise may result from many different factors. Apart from economic issues (e.g., economic crises, growing market fundamentalism, the stress on competition, and existential fears), cultural patterns are also important (Inglehart and Norris 2016). Regarding this latter problem, I tend to accept Philippe C. Schmitter's (2019) reasoning. He identified a range of patterns that either help maintain or degrade democracies:

1. Endogenous sources (like professionalisation and bureaucratisation of politics),

2. fortuna (i.e. luck, fate), 
3. virtu (the qualities of a nation), and

4. exogenous sources (like the rise of the Internet) (Schmitter 2019).

These factors in combination impact a population's social values, and then, affect legislation and policy-making, as well. For example, artificial ('fake') news and racism can spread more readily these days than in past decades (due to broadscale use of the Internet and other mobile devices). This does not mean the 'new' anti-Enlightenment values would necessarily come out of the blue: they were likely present, but hidden in the European countries' cultural environment.

The present article claims that one of the major sources of cynicism in the EU is the anti-Enlightenment tradition, which is present in all the member states as well as in the EU. Cynicism is defined in the MacMillan Dictionary as 'the attitude or behaviour of someone who is willing to let other people be harmed in order to get an advantage'. For the purposes of this article, we could state that a distinct legislative cynicism occurs when the actions of a politician representing the anti-Enlightenment tradition (partly or wholeheartedly) lead to a shift in policy-making, and the real aims behind such actions are not properly explained to the public. This means that it appears that the former consensus about Enlightenment values is not harmed, while, in reality, this is exactly the case. To put it in brief, it is like a fraud on voters and other actors, performed to minimise political resistance and maximise the public support for a political group, movement, or institution.

This cynicism can take two distinct forms. First, it is practiced by groups that use the intellectual elements of the anti-Enlightenment tradition extensively in their political rhetoric (a prime example for this is the far-right rhetoric so widespread in many European countries. This rhetoric is mostly based on the anti-Enlightenment tradition). Second, we can meet the cynicism of other actors as well. For example, when they meet actual problems, several (in theory, democratic) leaders of European countries and EU institutions either remain silent or use policies that do not conform to Enlightened universalism and rationality. This latter method has a devastating effect on policies, as it re-shapes the value framework of a community (including the EU, but also the values shared by the public in member states). As a result of these two forms of cynicism, policy-making in the EU has undergone elementary change. Furthermore, we must highlight that member states, but also EU leaders can use cynical strategies selectively: it would be false to claim politicians never tell truth, only lies. Probably, they use cynicism in situations when they feel other measures would not be as favorable to them.

This is also one reason why it is very hard to quantify the cynicism of politicians. To do so, we have to go through a two-step method. First, we have to ascertain that a politician does not tell the truth, or misrepresents facts. Second, we must assume that this is done deliberately, either because the politician concerned does not believe in certain common values, or because he or she can receive some support. The first step is relatively easy to prove: there is an extreme amount of research about the effect of fake news and there is also a great scientific debate whether we reached the post-truth era (see, e.g., Hyvönen 2018; Barrera et al. 2018; McIntyre 2018; Marshall and Drieschova 2018). As Hyvönen puts it, 
'Democratic formation of opinions... requires that some facts are settled. This is the properly political task truth can perform... (This is) ... nothing like the liberal market place of ideas, which is sometimes evoked as a process that leads to 'the truth' in the public sphere... Instead of being distilled from the plurality of perspectives, truth invites and makes possible the expression of different viewpoints. Factual truth stands at the beginning of the processes of agonal debate, of wooing and persuasion, not at their end. (Hyvönen 2018, 37)'.

This is why, politicians making invalid claims en masse endanger the democratic decision-making. At the domestic level, this attitude is well documented (see, e.g., the case of Brexit and post-truth: Marshall and Drieschova, 2018, or the techniques of politicians to attain power in Stanley 2018, where a complete subchapter called 'Unreality' analyses this problem).

However, if we go further, the next step, namely, to ascertain the motives of politicians is by far more problematic, because it is more or less based on the evaluation of the viewer. This does not mean that this evaluation would not have importance, though, especially, if it is built on hard facts. Who is a demagogue? What is a democracy? What is an authoritarian measure? What does rule of law mean? What is fake news? When does an action harm human dignity? There is no clearcut answer to these problems, and what we, scholars tend to do is that we still try to objectify them, through using factual analysis. This is how quantification is mixed with personal evaluation when we talk about cynicism in the EU.

\section{Critiques of the Duality of Traditions}

The idea of the duality of Enlightenment/anti-Enlightenment political tradition is, of course, also often criticized, particularly from three different perspectives.

First, scholars claim that Enlightenment thinkers also had unacceptable, 'antiEnlightened' views: from Rousseau to Kant, many of them incorporated authoritarian, anti-egalitarian, racist, sexist, or other problematic ideas. However, this is why, this article uses the term 'tradition'. A political-cultural tradition can contain certain elements that are crystallised through history. It is a regularly repeated mistake to claim that, if the major authors of the Enlightenment had objectionable ideas, we cannot talk about the Enlightenment tradition at all and their failed ideas must necessarily belong to the Enlightenment tradition. This is not true: the tradition developed, and from a diffuse set of ideas, it also became more recognizable over the course of history. To give an example, from a legal perspective, it first created the idea that each and every human deserves respect, then moved on to equality under the law, then extended this to all races and genders, and recently, after realizing that formal equality in itself is unsatisfactory, created the social state to support equal opportunities at the social level, as well.

Second, some critics claim that the Enlightenment was oppressive in nature, or claim that there were Enlightened patterns and elements rooted in the Enlightenment in oppressive systems like historical Fascism (Adorno and Horkheimer 2015; 
Fillafer 2007; Koselleck 1988; Ledeen 1976; Payne 2000). Both interpretations are wrong: scholars misinterpret the Enlightenment tradition when they claim that a stress on human dignity or individualism leads to oppression: this is a rhetorical deception. The same is true regarding the effects of Enlightenment elements on fascist regimes: it is not accurate to claim that Fascism was built on Enlightened ideas like rationalism, pluralism, universalism, or democracy, when, in effect, it served as a tribal system working against these values.

Third, scholars tend to criticize the idea of duality because of the diversity of political movements implementing elements of the anti-Enlightenment tradition. For example, Stalinism, radical left-wing forces, religious fundamentalism, ${ }^{1}$ and radical green movements (Pinker 2018) also implemented patterns from both traditions. Moreover, even democratic political streams can use dubious clichés, sometimes in an unintentional way. A great example of this is when we mix race with social policies to help minority groups, which has the potential to strengthen tribalism and ethnic conflicts. While this is done in good faith, and, in certain cases, such actions can have a role, an over-emphasis on race can change the universalist foundations of policy-making (Fukuyama 2018a, b). Thus, it is wrong to claim that similar antiEnlightened patterns could not be present in political/religious groups other than the Far Right. Of course, they can be present; this does not contradict the existence of the tradition, but only proves that human thinking can implement similar elements into different ideological systems, and also shows how dangerous it can be when similar elements receive mainstream support in different political or religious movements, because these can strengthen each other. For example, a stress on democratic fatigue and a desire to abolish the limitations of power or democratic decision-making can be present in many different political streams, and can serve as the foundations of a dangerous public consensus against public institutions.

\section{The Anti-enlightenment Tradition and Its Effect on Policy-Making}

In light of the above discussion, an interesting question arises: why and how does the anti-Enlightenment tradition affect policy-making at the European level? According to Jeffrey T. Checkel,

'[a]fter all, much is happening in Europe - supranational polity building, the creation of the Euro, socialisation beyond the nation state, the constitutionalisation of the EU, the creation of a European identity - that is strongly suggestive of a Westphalian system being transformed and of a nation state in retreat. While recognising the undeniable importance of such trends and facts, it would be a signal mistake for scholars to neglect the domestic and national.

\footnotetext{
1 For this connection, see Owen and Owen (2010) or the works of Bassam Tibi (__ $)$. Please note that strands of anti-Enlightenment sentiment can also be present in fundamentalist Christian streams, which deny the separation of church and state and use religion to back hatred against refugees. For examples, see the Hungarian Christian Democratic People's Party, Matteo Salvini's Lega and other political streams using Christianity for political purposes.
} 
Unfortunately, all too many researchers - be they classic integration theorists or constructivists - commit precisely this error... In making these connections to the domestic, EU constructivists should dynamically integrate factors across different levels of analysis - national and European, in this case. Dynamic means that one goes back and forth across levels, emphasising the simultaneity of international and domestic developments' (2006, 11-12).

In this constructivist system, EU law and policies are deeply rooted in national culture; moreover, the EU's architecture is also a form of the collective domestic political cultures of member states. Furthermore, national cultures have 'dual faces': in fact, there is a latent, phantom war of values in these societies. As a result, antiEnlightenment and Enlightenment elements are intermingled in everyday social practices and policy-choices. The causation (i.e., 'to find the proof of an existing tradition') in such cases is always a hard problem: it is the chink in the armor of constructivist social science. In EU integration, anti-Enlightenment elements in the EU could be present because of numerous reasons, not only because of member states' tradition: for example, they could be implemented into legislation because of bad compromises between member states. This article tries to overcome this serious pitfall through focusing on the policy outcomes (the final results of cooperation), and not necessarily on the institutional process they were created. This approach is in line with the modernist-constructivist approach, "where scholars combine an ontological stance critical of methodological individualism with a loosely causal epistemology. Analytically, they focus on the role of norms in social life, demonstrating that norms matter in a constitutive, interest-shaping way not captured by rationalist arguments' (Checkel 2001). This more 'mythic way' of the interpretation of European integration is interesting, if we see that very similar values are present in European both at EU and domestic levels. From this point, these problems can be quantified and measured: for example, the presence of xenophobia or authoritarianism can be easily measured in European societies (see CoE 2018). The same can be said about crimes committed by the far right in Europe (for example, Germany 'recorded over 22,000 right-wing extremist crimes' in 2019, see DW 2020).

From the point of the analysis of the actual policies of the EU, the fact why anti-Enlightenment values are present in domestic or EU level legislation and who (which countries or institutions) represent those values becomes less interesting. Consequently, when examining the effect of the anti-Enlightenment tradition from a general perspective, we have to separate its appearance in EU legislation and at the domestic level, but these two levels are in a direct connection with each other, through the institutional setting of the EU, and we can interpret the values represented by the EU though a snapshot of its legal system. Inter-institutional bargaining is less interesting for us now, as first their presence must be shown.

At the domestic level, the anti-Enlightenment tradition has the potential to reshape the constitutional framework of a country completely. Since it is against pluralism, tolerance, and respect for diversity, it eradicates checks and balances, occupies the constitutional courts, manipulates elections, spreads propaganda, and tries to secure its power. As László Kövér, the Speaker of the Hungarian parliament put it in a recent speech to the parliament, '[the] system of checks and 
balances, I do not know what you studied about it, is a stupid thing, it has nothing to do with neither rule of law, nor democracy.... The problem is that certain people take it seriously that the democratically elected government has to be limited' (Német 2019). This is a seemingly honest agenda setting against checks and balances. However, in a cynical way, if someone would raise that this change leads to oppression and concentrates all powers into the hands of a group or a leader, this would be denied by the proponents of these changes. Using propaganda, tribalism, identity politics, and fear as political tools, this tradition can convince many that its policies are progressive. In this regard, manipulation of public opinion (irrational emotionalism) and 'double-speak' can even be more useful than direct terror (Schedler 2002) In governmental systems in which such policies dominate, we can measure an inflation of the law, as it becomes a mere tool of power: the rule of law is changed to rule by law in state practices. Finally, one must also mention that anti-Enlightened elements can also be found in the laws of democratic countries. For example, most European states do not really separate church and state (Reichman 2018).

At the EU level, while the EU could be seen as a vanguard of many Enlightenment values like mutual respect, universalism, and respect for basic human rights, its architecture and substantive rules all contain elements that do not conform to the Enlightenment tradition. To pick certain points at random, the democratic deficit written about by Føllesdal and Hix still exists and produces technocratic, elite-centred law-making, (Føllesdal and Hix 2006) and it is too complicated for lay people to understand the course of legislative procedures. Moreover, in most cases, EU citizens cannot ask the CJEU directly for legislation to be annulled, even though they have to apply these rules. This is highly problematic: it shows the lack of democratic control of everyday people (a kind of elite-centred, postfeudal decision-making). Furthermore, discrimination based on citizenship or habitual residence is widely accepted, and, although we do not even recognise it, we thereby push universalism into the background in legislation. This discrimination is common in many policies, from visa-related rules to consumer law, and it has great practical relevance: for example, it is the reason why students from third countries must pay much higher tuition fees than domestic or EU students in many countries in Europe. We also have double standards in family reunification. Member States' fear of a strong EU human rights regime (see Art 51 of the Charter of Fundamental Rights) also shows that there is resistance to the Enlightenment tradition. Moreover, especially recently, the management of the Euro crisis contained many questionable elements (Kreuder-Sonnen 2016). A high number of such patterns in law have the potential to create a negative spiral in the EU (a cycle of authoritarianism, as Christian Kreuder-Sonnen calls this phenomenon see, Kreuder-Sonnen 2018). These elements are not necessarily a direct result of the representatives of the anti-Enlightenment tradition. However, they all contain a mark of how our domestic political cultures function, what values our leaders represent and how they want to codify these values into EU legislation. Furthermore, recently, many actions were the direct results of domestic political forces supporting anti-Enlightenment values (like the denial of humanism or human rights of refugees), as will be explained below. 


\section{Cynicism in Particular Fields}

\subsection{Human Rights and the Rule of Law Crisis}

One of the best examples of how the anti-Enlightenment tradition works is seen in the rule of law crisis in Europe (Pech and Scheppele 2017; Nagy 2018). This crisis has an effect on other fields (like refugee law) as well, so it has a central nature. In this regard, we can ascertain that the crisis is neither just a fundamental rights crisis nor just a political crisis (Kelemen 2017), but at its roots is a major value crisis, a struggle between the two value systems explained above. If we consider the drives behind the recent political and legal changes in Poland and Hungary (but also elsewhere in Europe, like in Italy or Germany), we can see that authoritarian actions always have something to do with the anti-Enlightenment tradition. For example, as mentioned above, this tradition is unable to accept tolerance, pluralism, and diversity, so is unable to accept the separation of powers. As a result, institutions like constitutional courts become elements in a facade of democracy, but do not have proper functions. For example, the constitutional court in Hungary nearly always follows the interpretations of the government (Eötvös Károly Institute, Hungarian Civil Liberties Union and Hungarian Helsinki Committee 2015). Another example is the attacks against judges in both Hungary and Poland (which have only been partially cured after EU actions in Hungary, as not all the judges have been given their jobs back, see Halmai 2017). Changes in electoral laws also show this authoritarian dynamic: since representatives of the anti-Enlightenment tradition believe that they are morally superior to representatives of other political streams, they allow themselves to modify electoral laws for their own benefit. This is very similar to the actions of political actors 200 years ago who did not want to give power to the people, and who sought the restoration or maintenance of monarchies all over Europe. The attacks against academic freedom (in both Poland and Hungary; see Ziegler 2019b) are also the direct result of aversion to pluralism: independent academia can be critical, diverse, and egalitarian; in short, it can serve as a threat to this tradition. The murder of Walter Lübcke in Germany also seems to be a direct result of this tradition: its aim is to eliminate opposing opinions. The same can be said about the Strache scandal in Austria: manipulating the press can be useful to eliminate the pluralist nature of these societies (we should not forget that pluralism is based on respect for individuals, freedom of conscience, and the idea of the equality of all people). At the legal level, many of the problems occur, because this tradition is unable to respect human rights and sees them as useless constraints on the achievement of its aims.

Please note that, unfortunately, in a number of cases, EU institutions have also accepted some of the clichés of this tradition. Not only did they breach many rules in certain areas (like asylum law, see below), but they also accepted a pseudo-originalist, extremely narrow interpretation of rules that would otherwise give some protection, like Articles 2 and 6 TEU or the applicability of the EU Charter of Fundamental Rights (Pech and Scheppele 2017; Jakab 2013, 2017). 
In relation to this kind of cynicism, Eric Posner writes that '[i]f Europeans cannot even compel a small, financially dependent country in their midst to comply with human rights, then one must infer that they do not care enough about human rights to devote substantial resources to them' $(2014,106)$.

The cynicism of the anti-Enlightenment tradition in this field lies in three facts. First, as in other cases, it cannot explain its true aims. It cannot advocate openly for oppression, for the silencing of critical opinions, for the abolition of checks and balances, or for the creation of a system whose main purpose is to keep anti-Enlightenment forces in power. In the beginning of the twentieth century, such aims could be openly expressed. At that time, politicians like Mussolini called openly for dictatorship and a totalitarian state, because people did not have experience of dictatorships. At the beginning of the twenty-first century, this open communicative framework would not work. Second, the anti-Enlightenment tradition hides behind democracy to justify anti-democratic moves, and claims that 'the nation' supports its actions. Apart from being a manipulative rhetorical cliché that can be used very successfully, this claim is not necessarily true. Even though Mussolini called his system 'authoritarian democracy' (Gentile and Mussolini 1935), it was not democracy at all. Today, even if protests are limited in certain countries, anti-EU rhetoric or the abolition of human rights is not necessarily supported by the voters (Starr 2017). Thus, the antiEnlightenment tradition cherry-picks topics like immigration to show its legitimacy, then using hatred to hide the subsequent democratic backlash. Third, the tradition reverses the meaning of sentences, and labels its opponents with the same expressions with which it is portrayed. For example, it became common for European postfascists to label their opponents as anti-democratic or even racist (because they support immigration and, according to their argument, their enemies 'do not want to help third countries'). The same can be said about calling anti-racism and anti-Fascism anti-democratic. While it is true that, in a proper democracy, the anti-Enlightenment tradition is pushed out of the public discourse with different techniques, this has one basic function: democracies could not exist if the anti-Enlightenment tradition prevailed, as it seriously harms the democratic framework. As a result, it creates electoral or closed autocracies (Schedler 2013), which are the modernised versions of the classic autocratic regimes.

\subsection{Refugee Law}

Another prime example of how the anti-Enlightenment tradition works is found in the reshaping of asylum law at both the EU and the domestic level (Peers 2019; Ziegler 2019c). In this area, several of its suppositions do not conform to the basic values of western democracies. First of all, it strips refugees of their individuality. When political forces claim that refugees are all rapists or terrorists, that they bring dangerous diseases to our countries, and that they want to invade Europe in the name of Islam, they base their arguments on an undifferentiated thinking about the arrivals. Enlightened universalism and individualism maintain that we must handle each and every person based on his/her own deeds; this method is portrayed by the anti-Enlightenment tradition as naivety. This has an effect on the eradication of 
human rights standards for groups other than those belonging to the mainstream of a nation. Second, to achieve this, the anti-Enlightenment tradition not only fails to respect political correctness, but also uses politically incorrect and unfair rhetorical techniques. Many of its claims are based on false data: the widespread fake news about extremely high number of crimes among migrants does not match reality. This leads us to the third problem, namely, that, as a result of the above, the anti-Enlightenment tradition supports emotional decision-making, instead of data analysis and fact-based arguments.

The cynicism of the anti-Enlightenment tradition in this field also lies in the fact that, in most cases, it does not openly explain its particularistic foundations. An open argument would be based on the fact that this tradition finds certain people to be inferior to 'cultured' white (probably Christian) Europeans because of their race, religion, or culture. A good example of the anti-Enlightenment tradition and its hidden language is the way in which the Hungarian MEP József Szájer referred to Game of Thrones and called refugees 'the army of death' (Novak 2017). What is very interesting here is that he did not mention zombies or inferior humans, but used more covert language to refer to the arrivals, triggering the connections only in those who knew the series. Such covert language is very useful, especially if it is backed by the racist, large-scale anti-refugee propaganda of the Hungarian government, which was able to re-shape public opinion about refugees in Hungary (Barna and Koltai 2019).

At the EU level, even the wording of documents has shown a change: refugees or asylum seekers have been turned into 'irregular migrants' in documents. ${ }^{2}$ The efforts to prevent refugees from entering the EU and to decide their cases in Africa before they arrive also shows hostile attitude towards them. Moreover, the EU-Turkey deal violates EU law and international law rules, but, when this was raised in a procedure, the CJEU used a trick of words and claimed that this was just a 'deal' made by the Member States in their own names (even if this area is covered by EU law, and the deal was announced on the website of the Council). ${ }^{3}$ In this way, the CJEU put this deal somewhere in a terrain where illegal rules should be applied against EU regulations in practice. Furthermore, concentrating on restrictive measures instead of saving people cost 2700 lives of people who drowned in the Mediterranean Sea in 2018, as a result of the EU's recall of rescue ships, and also, of Italy's actions against helpers. ${ }^{4}$ It is highly problematic to differentiate between the lives of those who belong to European nations and the lives of those who do not.

\footnotetext{
2 See e.g. EU-Turkey statement, 18 March 2016 https://www.consilium.europa.eu/en/press/press-relea ses/2016/03/18/eu-turkey-statement.

3 General Court of the European Union Press Release No 19/17; Order of the Court of 28 February 2017 in CJEU, Case T-192/16 NF v European Council. ECLI:EU:T:2017:128; Heijer and Spijkerboer (2016); Idriz (2017, 2018). "Today the Members of the European Council met with their Turkish counterpart." https://www.consilium.europa.eu/en/press/press-releases/2016/03/18/eu-turkey-statement/.

4 EU recalls ships helping in Mediterranean refugee rescues. Al Jazeera (March 27, 2019) https://www. aljazeera.com/news/2019/03/eu-recalls-ships-helping-mediterranean-refugee-rescues-190327135258098 .html?mc_cid=c8ed3e3539\&mc_eid=ea525a4cee; Marchesi (2019) pp. 67-76.
} 
At the domestic level, one can find even more problematic actions. Here, there is a constant struggle between the representatives of the two traditions. For example, sending refugees back to countries with poor conditions ${ }^{5}$ or detaining asylum seekers (as is done in Hungary, whose practice seems to be followed with a limited personal scope in a recent German law regarding those whose application is refused) is against international and EU law standards (Dearden 2017; Gehrke 2019). Detaining people before they are convicted does not conform to Enlightened principles. Certain countries (like Italy, but also partly Hungary) do not allow or strictly limit the right of refugees to enter their countries, thereby violating their international obligations (Carta 2018; Majtényi and Tamburelli 2019). The Hungarian government detained refugees in transit zones (in fact, in camps that are collections of small steel containers $)^{6}$ and deprived them from food for days. As a UN report puts it, 'since August 2018, at least 21 migrants awaiting deportation had been deprived of food by the Hungarian authorities—-some for up to five days'. ${ }^{7}$ Hostile xenophobia also changed the rules on non-refoulement: several countries send refugees back to third countries where they are not secure, thereby breaking the most important rule of refugee law. Even in German practice, one could question how Syrians or Afghans do not necessarily receive refugee status, but sometimes subsidiary protection or nothing. Furthermore, basic terms, like 'direct' arrival (see Article 31 of the Geneva Convention) or the available options for the criminalization of refugees (arriving with fake documents, for example), have been re-interpreted. Denying family reunification (see, for example, the German practice, Al-Jablawi 2019) is also deeply inhuman. Finally, the strong opposition to refugee quotas also shows the cynical attitude of the anti-Enlightenment tradition, which is interested in creating chaos Europe-wide. Special agreements (like those between Italy and Libya, or between Germany and Greece, see Lübbe 2019) do not lead us to a more human and problem-based solution to our joint European problems, either. Moreover, as Thomas Gross put it regarding the new German reforms, "there are a few former refugees whose status hasn't been recognized. They will get a more long-term "toleration status" under very tight restrictions. But that isn't a residency permit, but a second-class, uncertain status...' (Knight 2019). Finally, keeping people detained in horrible conditions in camps at the borders of Europe for years (like in Greece, for example, but also in Italy and Hungary) also shows the cynical element in European politics.

To summarize, the consensus on acceptance, universal human values, human dignity, and the belief in a sense of joint cooperation between cultures, countries, and religions seems to be damaged or endangered, Europe-wide. Even countries that portray themselves as open and Enlightened use techniques that can be seriously

\footnotetext{
5 CJEU, Joined Cases C-297/17, C-318/17, C-319/17 and C-438/17. Bashar Ibrahim and Others v Bundesrepublik Deutschland and Bundesrepublik Deutschland v Taus Magamadov ECLI:EU:C:2019:219.

${ }^{6}$ ECtHR, Ilias and Ahmed v Hungary (no. 47287/15) [2017] ECHR 255.

7 Press briefing notes on Iran and Hungary-UN High Commissioner for Human Rights, 3 May 2019 https://www.ohchr.org/EN/NewsEvents/Pages/DisplayNews.aspx?NewsID=24551\&LangID=E.
} 
questioned, which shows a change of these values in legislation. Openness has become a rhetorical tool, while, in reality, cynicism has eroded the basic values in this field. Unfortunately, even the Strasbourg Court seems to follow these changes. ${ }^{8}$

\subsection{Brexit}

The exit of the UK from the EU could also provide many examples of the nature and actions of the anti-Enlightenment tradition. What one can relatively easily understand is that Brexit is a result not only of economic issues (especially the hardship of lower middle class workers), but also of political culture (which, of course, also includes economic aspects). In relation to the exit of the UK, the public discourse in the UK was dominated by derogatory statements about the EU. ${ }^{9}$ Many of these statements were false (fake news became widespread): the EU is not an oppressive organization, and it has no right to force Member States to accept immigrants (most of the rules it has adopted are about refugees and short-term visas, while for the long term, it has only made some supplementary rules). ${ }^{10}$ The Brexit campaign also had a very strong nativist-xenophobic tone. In 2016, a Member of Parliament, Jo Cox, was murdered, which shows that the British political culture contains very similar authoritarian (totalitarian) elements to the continental one. Moreover, it shows that, instead of rational analysis, emotionalism dominates. As this article has already explained, there are numerous reasons why the EU could be criticized. However, a re-structuring of the institutions' powers, a simplification of law-making, or greater access for EU citizens to decision-making, were never seriously raised by the UK.

Consequently, Dora Kostakopoulou seems to be right when she claims that this attitude shows a lack of commitment to the EU by the UK (Kostakopoulou 2018, 2017). Furthermore, if we extend the scope of our investigation, we can find that Paul Beaumont, Danny Dorling, and Sally Tomlinson are all right when they claim that Brexit is caused by a post-colonial delusion (Beaumont 2017; Dorling and Tomlinson 2019). This delusion is made of the many anti-Enlightenment elements present in British political culture. I personally believe that belonging to this delusion is a kind of exceptionalism based on the false supremacy of a nation and its members, racism (supremacism), and the authoritarian desire of dominance over other people, countries, and political forces inside and outside the country. Based on a logic presented by Timothy Snyder, this attitude has the potential to create smaller and smaller ethnic communities all around Europe ${ }^{11}$ (Snyder 2018a, b), and, in the long term, it also leads to a strengthening of authoritarian politics. Using

\footnotetext{
${ }^{8}$ See the Grand Chamber's decision on the detention of asylum seekers in Ilias et Ahmed v. Hongrie (Case 47,287/15).

9 'The Reuters Institute for the Study of Journalism (2016) found that $41 \%$ of articles about the EU were negative and just 27\% were positive, while 6 out of the 9 national newspapers took a pro-leave stance', Beaumont (2017), p. 387.

10 See Council Directive 2003/109/EC of 25 November 2003 concerning the status of third-country nationals who are long-term residents OJ L 16, 23.1.2004. 44-53.

11 Snyder claims that many European nations want to return to ethnically homogenous nation states that never existed: see Snyder,(2018a), p. 77; Snyder (2018b).
} 
gerrymandering, as was done in the UK against UKIP earlier, even strengthens this process for short-term goals.

What made many of the Brexiteers' arguments cynical is that most of their fundamental presuppositions could not be openly expressed. There is a chance that any political force that openly advocated the grandeur of white, Christian Englishmen dominating and colonizing most of the world would find itself on the sidelines of politics in the UK. Consequently, they could not claim that their culture was higher and better than that of others, and they also could not claim that third world people and their countries were worse than them. They could not openly express their view that they were more emotional than rational, that economic data are uninteresting, and that the negative effects of this political process (which will surely appear) do not bother them at all. In this emotion-based worldview, the UK is still a worlddominating empire with a strong international presence which stands somewhere between the US and Europe. A clear view of the data shows this is not true, and that the UK's trade with continental Europe is (and, perhaps, always will be) greater than its trade with the US or with any other countries of the world. In summary, the cynicism of Brexit is that it could not openly confess that it was working to reach a new, imaginary, unreachable colonial dominance of an empire over other nations and their people, and therefore, it used many different strategies to cheat and deceive people and boost its support.

\subsection{The Single European Market}

A less well-known aspect of the anti-Enlightenment tradition is that, in many countries, it tries to exclude foreign investors from certain sectors. A lighter form of this protectionism is present in many countries all over Europe ${ }^{12}$ (Robinson 2017; Segreti 2018).

However, the anti-Enlightenment tradition boosts these tendencies by creating oligarchic market circumstances, as happened in Hungary (Ziegler 2016). In such systems, oligarchs (Kovacs 2018) receive huge amounts of assets as a result of policies that re-shape the market and of corrupt public procurement (Ziegler 2019a). Some of these actions comply with EU law, but others do not (Ziegler 2016).

The cynicism of the anti-Enlightenment tradition lies in its attempt to hide the fact that it wants to create a 'new nobility' and hierarchic social structures around a party or a party's leaders, to finance its politics (Magyar 2016). The original aim to support the oligarchs (through the violation of provisions on the single market, state aid or public procurement) cannot be expressed openly. Consequently, it must be hidden behind nationalistic arguments about the protection of domestic interests. However, this is not economic patriotism (cf. Varju and Papp 2016) and there is a

\footnotetext{
12 CJEU, Case C-265/95. Commission of the European Communities v French Republic. European Court Reports 1997 I-06959 ECLI:EU:C:1997:595; Several tons of Spanish stonefruit burned in PerpignanSpanish agricultural sector demands sanctions against French attacks. Fresh Plaza (Aug. 7, 2014) https:// www.freshplaza.com/article/2123244/spanish-agricultural-sector-demands-sanctions-against-french-attac ks; Robinson (2017); Segreti (2018).
} 
strong chance that the wealth such oligarchs receive will not necessarily boost the domestic industry, as its main aim is to stabilize the position of the forces of the anti-Enlightenment tradition.

What we must also point out at this stage is that such political forces do not necessarily exclude investors from all sectors: if these forces see that they can get incentives or do not have direct interests, they can even support certain foreign businesses. A good example of this is the case of German automobile companies in Hungary, which even receive state support (while investors in the supermarket sector and the banking system are pushed out of the market). This then has the potential to backfire: as a result of their status, foreign companies that receive subsidies become interested in stabilizing the power structure in the country (Klawitter 2018; Langowski 2018).

Reactions to similar actions also show the danger that this tradition can be accepted. For example, in a highly cynical way, the German Chancellor Angela Merkel recently expressed her opinion that "when talking about the objective of the Cohesion Funds and the Structural Funds, it has to be said that they are set up to increase convergence within the European Union. Looking at the economic growth rate of Hungary, it is obvious that Hungary has used those funds well to benefit its people' (Cseresnyés 2019). All this, when billions of Euros coming from the EU are flowing into the oligarchic system in the country: no wonder Bálint Magyar calls this the post-communist mafia state (Magyar 2016). Other policies (like cutting welfare measures and the introduction of public work programmes, where participants depend heavily on decision-makers) even strengthen post-feudal, hierarchic social structures.

\section{Conclusions}

It is important to refute the cynicism of the anti-Enlightenment and strengthen the values of the Enlightenment in our societies, both at the domestic level and in the EU. Most European societies live in latent denial in this regard: many simply do not want to face the anti-Enlightenment elements in their legal systems or social practices. This is also one reason why, even if the tendencies we see today are very similar to those we saw a hundred years ago, a more analytical and critical European social, political, and legal science connecting the similarities in our history is mostly missing. As a result of this, countries find it difficult to strengthen opposing values.

Francis Fukuyama is wrong when he claims that the new tribalism in the Western world started in the sixties (Fukuyama 2018b) — it had much older traditions both in the EU and in the US. However, he is right when he claims that it is a mistake not to recognise and teach the basic, Enlightened principles on which our societies are built, and a mistake not to create a mainstream culture surrounding them. As he puts it:

'[N]early 20 years ago, a German academic of Syrian origin named Bassam Tibi proposed making Leitkultur (leading culture) the basis for a new German national identity. He defined Leitkultur as a belief in equality and democratic 
values firmly grounded in the liberal ideals of the Enlightenment. Yet leftist academics and politicians attacked his proposal for suggesting that such values were superior to other cultural values; in doing so, the German left gave unwitting comfort to Islamists and far-right nationalists, who have little use for Enlightenment ideals. But Germany and other major European countries desperately need something like Tibi's Leitkultur. a normative change that would permit Germans of Turkish heritage to speak of themselves as German, Swedes of African heritage to speak of themselves as Swedish, and so on.' Fukuyama, (2018b, 107).

A symbol of the misinterpretation of the dangers posed by the anti-Enlightenment tradition can be seen in the German Constitutional Court's NPD judgment: a Nazi party is allowed to exist and advertise itself on television, because it 'does not represent danger to society'. ${ }^{13}$ By accepting 'lighter', watered-down elements of this tradition and codifying them (as is done in many countries in Europe regarding refugee law), nations disregard the positive elements in their political culture that they have already achieved. There is no compromise between the two groups of values, and if one prevails, the other loses. We have a tradition which could be used as a shield against many of the negative tendencies occurring today. However, to use it, first we must face the dark side of our political culture and legal systems. The lack of self-reflection may cause crises and disintegration in the Western world, both at the international level and inside these societies.

Funding Open access funding provided by Eötvös Loránd University.

\section{Compliance with Ethical Standards}

Conflict of interest The author has no conflict of interest concerning the topic of this paper.

Open Access This article is licensed under a Creative Commons Attribution 4.0 International License, which permits use, sharing, adaptation, distribution and reproduction in any medium or format, as long as you give appropriate credit to the original author(s) and the source, provide a link to the Creative Commons licence, and indicate if changes were made. The images or other third party material in this article are included in the article's Creative Commons licence, unless indicated otherwise in a credit line to the material. If material is not included in the article's Creative Commons licence and your intended use is not permitted by statutory regulation or exceeds the permitted use, you will need to obtain permission directly from the copyright holder. To view a copy of this licence, visit http://creativecommons.org/licen ses/by/4.0/.

\section{References}

Adorno, Theodor, and M. Horkheimer. 2015. Dialectic of enlightenment. Stanford: Stanford University Press.

\footnotetext{
13 'No prohibition of the National Democratic Party of Germany as there are no indications that it will succeed in achieving its anti-constitutional aims', Press Release No. 4/2017 of 17 January 2017. Judgment of 17 January 20172 BvB 1/13, https://www.bundesverfassungsgericht.de/SharedDocs/Pressemitt eilungen/EN/2017/bvg17-004.html.
} 
Al-Jablawi, H. 2019. Syrian refugees' struggle with temporary status in Germany. Atlantic Council, February 26, 2019. https://www.atlanticcouncil.org/blogs/syriasource/syrian-refugees-struggle-withtemporary-status-in-germany/.

Antonio, R. 2000. After postmodernism: Reactionary tribalism. American Journal of Sociology 106 (40): 40-87.

Barrera, O., S. Gurievb, E. Henry, and E. Zhuravskaya. 2018. Facts, alternative facts, and fact checking in times of post-truth politics. Journal of Public Economics 182 (3): 1-19.

Barna, I., and J. Koltai. 2019. Attitude changes towards immigrants in the turbulent years of the 'migrant crisis' and anti-immigrant campaign in Hungary. Intersections: East European Journal of Society and Politics 5 (1): 48-70.

Beaumont, P. 2017. Brexit, retrotopia and the perils of post-colonial delusions. Global Affairs 3 (4-5): 379-390.

Berlin, I. 1979. The counter-Enlightenment. In Against the current: Essays in the history of ideas, ed. H. Hardy, 1-35. New Jersey: Princeton University Press.

Berlin, I. 2002. Freedom and its betrayal: Six enemies of human liberty. New Jersey: Princeton University Press.

Börzel, T., and T. Risse 2018. A litmus test for European integration theories: Explaining crises and comparing regionalisms. KFG Working Paper No. 85

Carta S. 2018. Beyond closed ports: The new Italian Decree-Law on Immigration and Security. EU Immigration and Asylum Law and Policy. http://www.eumigrationlawblog.eu/beyond-closed-ports-thenew-italian-decree-law-on-immigration-and-security/. Accessed 1 June 2020.

Council of Europe. 2018. Unrelenting rise in xenophobic populism, resentment, hate speech in Europe in 2017. https://www.coe.int/en/web/special-representative-secretary-general-migration-refug ees/newsletter-july-2018/-/asset_publisher/cVKOAoroBOtI/content/unrelenting-rise-in-xenop hobic-populism-resentment-hate-speech-in-europe-in-2017?_101_INSTANCE_cVKOAoroBO tI_viewMode=view/. Accessed 1 June 2020.

DW German far-right crimes rise (DW April 7, 2020) https://www.Germany recorded over 22,000 rightwing extremist crimes last year dw.com/en/german-far-right-crimes-rise/a-53053279. Accessed 1 June 2020.

Checkel J.T. 2006. Constructivist approaches to European integration available at http://www.follesdal. net/projects/ratify/TXT/Checkel-SageHandbookChapter.pdf. Accessed 1 June 2020. Also published as Jeffrey T. Checkel. 2006. Constructivist Approaches to European Integration. In Handbook of European Union Politics (Eds. Knud Erik Jorgensen, Mark Pollack, Ben Rosamond). Sage Publication.

Checkel, J.T. 2001. Why comply? Social learning and European identity change. International Organization 55 (3): 553-588.

Copsey, N. 2013. 'Fascism... but with an open mind'-reflections on the contemporary far right in (Western) Europe. Fascism 2 (1): 1-18.

Cseresnyés P. 2019. Did Merkel really praise Hungary for use of EU funds? Proof ends debate. Hungary Today, October 21, 2019. https://www.hungarytoday.hu/did-merkel-really-praise-hungary-for-useof-eu-funds-proof-ends-debate/. Accessed 1 June 2020.

Dearden, L. 2017. Hungarian parliament approves law allowing all asylum seekers to be detained. The Independent, March 7, 2017. https://www.independent.co.uk/news/world/europe/hungary-parli ament-asylum-seekers-detain-law-approve-refugees-immigration-crisis-arrests-border-a7615486. html. Accessed 1 June 2020.

Dorling, D., and S. Tomlinson. 2019. Rule britannia: Brexit and the end of empire. London: Biteback Publishing.

Eppler A, L.H. Anders, T. Tuntschew. 2016. Europe's political, social, and economic (dis)integration: Revisiting the elephant in times of crises. IHS Political Science Series, Working Paper 143.

Eötvös Károly Institute, Hungarian Civil Liberties Union and Hungarian Helsinki Committee (2015) Analysis of the performance of Hungary's 'one-party elected' constitutional court judges between 2011 and 2014: Executive summary. http://www.helsinki.hu/wp-content/uploads/EKINT-HCLUHHC_Analysing_CC_judges_performances_2015.pdf. Accessed 1 June 2020.

Fillafer, F.L. 2007. The Enlightenment on trial: Koselleck's interpretation of Aufklärung. In The many faces of Clio: Cross-cultural approaches to historiography, ed. F.L. Fillafer and E.Q. Wang, 322445. New York: Berghahn.

Finchelstein, F. 2014. Returning populism to history. Constellations 21 (4): 467-482.

Finchelstein, F. 2017. From fascism to populism in history. Los Angeles: University of California Press. 
Føllesdal, A., and Simon Hix. 2006. Why there is a democratic deficit in the EU: A response to Majone and Moravcsik. Journal of Common Market Studies 44 (3): 533-562.

Fukuyama, F. 2018. Identity: The demand for dignity and the politics of resentment. New York: Farrar, Straus and Giroux.

Fukuyama, F. 2018. Against identity politics. Foreign Affairs, September/October 2018. https://www. foreignaffairs.com/articles/americas/2018-08-14/against-identity-politics-tribalism-francis-fukuy ama. Accessed 1 June 2020.

Gehrke, L. 2019. German Cabinet passes deportation draft bill at odds with EU law. Politico, April 18, 2019. https://www.politico.eu/article/german-asylum-seekers-deportation-prison. Accessed 1 June 2020.

Gentile, E., and B. Mussolini 1935. The doctrine of fascism, encyclopedia of fascism. http://www.world futurefund.org/wffmaster/Reading/Germany/mussolini.htm. Accessed 1 June 2020.

Halmai, G. 2017. The early retirement age of the Hungarian judges. In EU law stories:Contextual and critical histories of European jurisprudence, ed. F. Nicola and B. Davies, 471-488. Cambridge: Cambridge University Press.

Hayek, F.A. 1978. The constitution of liberty. Chicago: University of Chicago Press.

Heijer, M.D., and T. Spijkerboer. 2016. Is the EU-Turkey refugee and migration deal a treaty? EU Law Analysis, April 7. 2016. http://www.eulawanalysis.blogspot.com/2016/04/is-eu-turkey-refugeeand-migration-deal.html. Accessed 1 June 2020.

Hyvönen, A.-E. 2018. Careless speech: Conceptualizing post-truth politics. New Perspectives 26 (3): $1-37$.

Idriz, N. 2017. Taking the EU-Turkey deal to court?" Verfassungsblog, December 20, 2017. https://www. verfassungsblog.de/taking-the-eu-turkey-deal-to-court/. Accessed 1 June 2020.

Idriz, N. 2018. The EU-Turkey statement or the 'refugee deal': The extra-legal deal of extraordinary times? In The migration crisis? Criminalization, security and survival ed. Siegel, D, V. Nagy. Netherlands; Eleven Publishing; also available as T.M.C. Asser Institute for International \& European Law Research Paper No. 2017-06.

Inglehart, R., and P. Norris. 2016. Trump, Brexit, and the rise of populism: Economic have-nots and cultural backlash. Harvard Kennedy School Faculty Research, Working Paper Series RWP16-026. https://www.research.hks.harvard.edu/publications/getFile.aspx?Id=1401. Accessed 1 June 2020.

Inglehart, R. 2018. The age of insecurity: Can democracy save itself? Foreign Affairs, (May-June 2018): 20-28.

Jakab, A. 2013. Supremacy of the EU Charter in national courts in purely domestic cases. Verfassungsblog, March 27, 2013. https://www.verfassungsblog.de/the-eu-as-a-community-of-human-rights/. Accessed 1 June 2020.

Jakab, A. 2017. Application of the EU Charter in national courts in purely domestic cases. In The enforcement of EU law and values - ensuring member states' compliance, ed. A. Jakab and D. Kochenov, 252-264. Oxford: Oxford University Press.

Jones, E. 2018. Towards a theory of disintegration Journal of European Public Policy. Journal of European Public Policy 25 (3): 440-451.

Kelemen, D.R. 2007. Built to last? The durability of EU federalism. In The state of the European Union making history: European integration and institutional change at fifty, ed. S. Meunier and K.R. Mcnamara, 51-66. Oxford: Oxford University Press.

Kelemen, D. R. 2017. Europe's other democratic deficit: national authoritarianism in Europe's democratic union, Government and Opposition Special Issue: 211-238.

Klawitter, N. 2018. Warum Audi und Daimler mit Orbán bestens zurechtkommen, Spiegel, October 10, 2018. https://www.spiegel.de/plus/warum-deutsche-unternehmen-in-ungarn-so-gut-zurechtkommen-a-00000000-0002-0001-0000-000159786792. Accessed 1 June 2020.

Knight, B. 2019. German government defends planned immigration laws. $D W$. https://www.dw.com/en/ german-government-defends-planned-immigration-laws/a-48676952. Accessed 1 June 2020.

Koselleck, R. 1988. Critique and crisis: Enlightenment and the pathogenesis of modern society. Boston: MIT Press.

Kostakopoulou, D. 2017. What fractures political unions? Failed federations, Brexit and the importance of political commitment. European Law Review 42 (3): 339-352.

Kostakopoulou, D. 2018. Institutional constructivism in social sciences and law-frames of mind, patterns of change. Cambridge: Cambridge University Press. 
Kovacs, Z. 2018. Forbes: Hungarian PM's friend became the wealthiest person in Hungary. Index, December 28, 2018. https://www.index.hu/belfold/2018/12/28/forbes_hungary_wealthiest_riche st_friend_orban_meszaros_billion_euro. Accessed 1 June 2020.

Krastev, I. 2012. A fraying union. Journal of Democracy 23 (4): 23-30.

Kreuder-Sonnen, C. 2016. Beyond integration theory: The (anti-)constitutional dimension of European crisis governance. Journal of Common Market Studies 54 (6): 1350-1366.

Kreuder-Sonnen, C. 2018. An authoritarian turn in Europe and European studies? Journal of European Public Policy 25 (3): 452-464.

Kunz, B. 2013. Integration, disintegration and the international system. A realist perspective on push and pull factors in European integration. In Zur Konzeptionalisierung europäischer Desintegration Zug- und Gegenkräfte im europäischen Integrationsprozess- Edited by Eppler A, H. Scheller 71-88. Baden-Baden: Nomos.

Langowski J. 2018. Die größten Firmen Ungarns stammen aus Deutschland. Der Tagesspiegel https ://www.tagesspiegel.de/wirtschaft/osteuropa-die-groessten-firmen-ungarns-stammen-aus-deuts chland/23239694.html.

Ledeen, M. 1976. Introduction. In Fascism: An informal introduction to its theory and practice, ed. R.D. Felice, 7-20. London: Taylor and Francis.

Lübbe, A. 2019. Administrative Court of Munich on Seehofer push backs: No protection of interim legal protection? Verfassungsblog, May 11, 2019. https://www.verfassungsblog.de/admin istrative-court-of-munich-on-seehofer-push-backs-no-protection-of-interim-legal-protection/. Accessed 1 June 2020.

Majtényi, B., and G. Tamburelli, eds. 2019. Human rights of asylum seekers in Italy and Hungaryinfluence of international and EU law on domestic actions. The Hague: G. Giappichelli \& Eleven Publishing.

Magyar, B. 2016. Post-communist Mafia state: The case of Hungary. Budapest: CEU Press.

Mammone, A. 2009. The eternal return? Faux populism and contemporarization of neo-Fascism across Britain, France and Italy. Journal of Contemporary European Studies 17 (2): 171-192.

Marchesi, A. 2019. Preventing the exercise of the right of asylum: The human cost of Italy's pushback policy. In Human Rights of Asylum Seekers in Italy and Hungary, Majtényi B, G. Tamburelli, 67-76. Publisher?!?

Marshall, H., and Drieschova, A. 2018. Post-truth politics in the UK's Brexit referendum. New Perspectives. 26: 3, No. 3/2018 89-105

Mazower, M. 2016. Fascism and democracy today: What use is the study of history in the current crisis?. European Law Journal 22 (3): 375-385.

McGaughey, E. 2018. Fascism-lite in America (or the social ideal of Donald Trump. British Journal of American Legal Studies 7 (2): 291-315.

McIntyre, L. 2018. Post-truth. Cambridge: MIT Press.

Mosse, G. 1981. The crisis of German ideology: Intellectual origins of the Third Reich. New York: Schocken.

Nagy, Cs. I., ed. 2018. The EU bill of rights' diagonal application to member states-comparative perspectives of Europe's human rights deficit. The Hague: Eleven Publishing.

Német, T. 2019. Kövér: A fékek és egyensúlyok rendszere hülyeség, azt felejtsék el! [The System of Checks and Balances is a stupidity, you should forget it!] Index, October 23, 2019. https://www. index.hu/belfold/2019/10/23/kover_laszlo_valasztas_ellenzek_rendszervaltas/. Accessed 1 June 2020.

Norris, P., and R.F. Inglehart. 2019. Cultural backlash: Trump, Brexit, and authoritarian populism. Oxford: OUP.

Novak, B. 2017. József Szájer admits to comparing refugees to zombies in town hall speech. Budapest Beacon, November 6, 2017. https://www.budapestbeacon.com/jozsef-szajer-acknowledgesessentially-comparing-refugees-to-zombies-in-town-hall-speech. Accessed 1 June 2020.

Owen, J.M., and J.J. Owen, eds. 2010. Religion, the Enlightenment, and the new global order. New York: Columbia University Press.

Payne, S.G. 2000. Historical fascism and the radical right. Journal of Contemporary History 35 (1): 109-118.

Pech, L., K. L. Scheppele. 2017. Illiberalism within: Rule of law backsliding in the EU. Cambridge Yearbook of European Legal Studies 3-47 
Peers, S. 2019. The Orbanisation of EU asylum law: The latest EU asylum proposals. EU Law Analysis,EU Law Analysis, May 6, 2019. http://www.eulawanalysis.blogspot.com/2016/05/theorbanisation-of-eu-asylum-law.html. Accessed 1 June 2020.

Pinker, S. 2018. Enlightenment now: The case for reason, science, humanism, and progress. New York: Viking.

Pinker, S. 2019. Enlightenment Wars: Some Reflections on 'Enlightenment Now', One Year Later. https://www.quillette.com/2019/01/14/enlightenment-wars-some-reflections-on-enlightenmentnow-one-year-later/. Accessed 1 June 2020.

Posner, E. 2014. The twilight of human rights. Oxford: Oxford University Press.

Reichman, R. 2018. Warum sich das Oberste Gericht mit der Frage beschäftigt, wer Jude ist. Jüdische Allgemeine. Jüdische Allgemeine, May 18, 2018. https://www.juedische-allgemeine.de/religion/ religion-oder-abstammung/. Accessed 1 June 2020.

Robinson, B. 2017. Macron attacks Italy: EU cracks appear as French leader takes on Italians in shipyard row. Express, July 28, 2017. https://www.express.co.uk/news/world/833794/Emmanuel-Macro n-angered-Italy-STX-France-shipyard-Atlantic-coast-Fincantieri-takeover. Accessed 1 June 2020.

RT. 2015. The dictator is coming': Juncker trolls Hungarian PM Orban. YouTube video, 0:25 Posted May 22, 2015. https://www.youtube.com/watch?v=juFxBhDSK9s. Accessed 1 June 2020.

Salomon, T. 2016, Die Juden müssen sehr aufpassen. Jüdische Allgemeine, available at https://www.juedi sche-allgemeine.de/article/view/id/27074. Accessed 1 June 2020.

Schedler, A. 2002. The menu of manipulation. Journal of Democracy 13 (2): 36-50.

Schedler, A. 2013. The politics of uncertainty-sustaining and subverting electoral authoritarianism. Oxford: Oxford University Press.

Scheller H., and A. Eppler. 2014. European disintegration-non-existing phenomenon or a blind spot of European integration research? Preliminary thoughts for a research agenda. University of Vienna, Institute for European Integration Research Papers, Working Paper No. 02/2014.

Schmitter, P.C. 2012. A way forward? Journal of Democracy 23 (4): 39-46.

Schmitter, P.C., and Z. Lefkofridi. 2016. Neo-functionalism as a theory of disintegration. Chinese Political Science Review 1 (1): 1-29.

Schmitter, P.C. 2019. Real-existing' democracy and its discontents: sources, conditions, causes, symptoms, and prospects. Chinese Political Science Review 4 (2): 149-163.

Segreti, G. 2018. Italy court confirms suspension of Telecom Italia fine over Vivendi control. Reuters, July 5, 2018. https://www.reuters.com/article/us-telecom-italia-vivendi-fine/italy-court-confirmssuspension-of-telecom-italia-fine-over-vivendi-control-idUSKBN1JV0V0. Accessed 1 June 2020.

Snyder, T. 2018. The road to unfreedom: Russia, Europe, America. New York: Tim Duggan Books.

Snyder, T. 2018b. Timothy Snyder speaks, ep. 16: The European Union. YouTube video, 20:36. Posted July 7, 2018. https://www.youtube.com/watch?v=nziEATOj5Yk. Accessed 1 June 2020.

Stanley, J. 2018. How fascism works-the politics of us and them. New York: Random House.

Starr, K. J. 2017. Tepid support for democracy among both young and old in Central and Eastern Europe. PEW, June 8, 2017. https://www.pewresearch.org/fact-tank/2017/06/08/tepid-support-for-democ racy-among-both-young-and-old-in-central-and-eastern-europe. Accessed 1 June 2020.

Sternhell, Z. 2009. The anti-Enlightenment tradition. New Haven: Yale University Press.

Sternhell, Z. 2014. Faschismus ist Teil unserer Kultur. Spiegel, July 7, 2014. http://www.magazin.spieg el.de/EpubDelivery/spiegel/pdf/127985806. Accessed 1 June 2020.

Taylor, P. 2008. The end of European integration-anti-Europeanism examined. London: Routledge.

Varju, M., and M. Papp. 2016. The crisis, national economic particularism and EU law: What can we learn from the Hungarian case? Common Market Law Review 53 (6): 1647-1674.

Vollaard, H. 2018. European disintegration—a search for explanations. London: Palgrave.

Waldron, J. 2014, Isaiah Berlin's Neglect of Enlightenment Constitutionalism. NYU School of Law, Public Law Research Paper No. 14-12. https://www.ssrn.com/abstract=2410388. https://doi. org/10.2139/ssrn.2410388. Accessed 1 June 2020.

Webber, D. 2014. How likely is it that the European Union will disintegrate? A critical analysis of competing theoretical perspectives. European Journal of International Relations 20 (2): 341-365.

Wodak, R., and J.E. Richardson, eds. 2013. Analysing fascist discourse: European fascism in talk and text. London: Routledge.

Wokler, R. 2012. Rousseau, the age of Enlightenment, and their legacies. Princeton: Princeton University Press.

Ziegler, T.D. 2016. The links between human rights and the single European market-discrimination and systemic infringement. Comparative Law Review 1: 1-23. 
Ziegler, T.D. 2019a. Anti-Enlightenment in international business and trade law: A US-EU comparison. Hofstra Journal of International Business and Law (forthcoming).

Ziegler T. D. 2019b. Academic freedom in the European Union-why the single European market is a bad reference point. Max Planck Institute for Comparative Public Law \& International Law, Research Paper No 2019-03.

Ziegler, T.D. 2019. EU asylum law: Disintegration and negative spillovers. In Human rights of asylum seekers in Italy and Hungary -influence of international and EU law on domestic actions, ed. B. Majtényi and G. Tamburelli, 21-42. The Hague: Giappichelli \& Eleven Publishing.

Tamas Dezso Ziegler is an associate professor at the Faculty of Social Sciences of Eötvös Lorand University (Budapest). His major is EU law and European studies. He has held numerous visiting positions, including visiting professorships at Bergen University (Norway), Warwick University (Coventry, the UK), Northwestern Polytechnical University (Xi'an, China), was a fellow of Free University Berlin, a Van Calker Fellow of the Swiss Institute of Comparative Law (Lausanne), a visiting scholar of Fordham University School of Law (New York), a visiting fellow (grant holder) of Max Planck Institute on Comparative and International Private Law (Hamburg), a visiting fellow (grant holder) of Max Planck Institute for Comparative Public Law and International Law (Heidelberg), and a guest researcher of the Contestations of the Liberal Script (Scripts) research project of the Otto-Suhr-Institute of Free University Berlin. 